\title{
PRAEINANTIS SMEGENŲ IŠEMIJOS PRIEPUOLIS, IŠEMINIS INSULTAS IR PERIFERINIŲ ARTERIJŲ LIGA
}

\author{
Liudmila Kimševaitė, Narimantas Markevičius \\ Vilniaus miesto klinikine ligoniné
}

Raktažodžiai: praeinantis smegenų išemijos priepuolis, išeminis insultas, periferinių arterijų liga.

\begin{abstract}
Santrauka
Darbo tikslas. Išanalizuoti sergančiųjų periferinių arterijų liga galvos smegenų kraujotakos sutrikimus, atkreipiant dèmesị $i$ išeminio insulto ir periferinių arterijų ligos ryši. Tyrimo medžiaga ir metodai. Vilniaus miesto klinikinès ligoninès Kraujagyslių chirurgijos, Invazinès radiologijos ir endoprotezavimo skyriuose bei Anesteziologijos angiochirurgijos reanimacijoje $2017 \mathrm{~m}$. vasarị - $2019 \mathrm{~m}$. birželị tyrème 28 ligonius (10 moterų, 18 vyrų), kurie sirgo periferinių arterijų liga ir galvos smegenų kraujotakos sutrikimais. Tiriamujų amžius - 49-87 metai (vidurkis $-73,2 \pm 1,9$ metų). Vidutinè stacionarinio gydymo trukmè - 7,7 dienos. Palyginamają grupę sudarè 11 lètine galvos smegenų išemija sergančių asmenų. Visiems ligoniams atliktas bendrasis ir biocheminis kraujo tyrimas (fibrinogeno, C-reaktyvinio baltymo koncentracija kraujo serume, lipidograma), elektrokardiograma, konvencinè arteriografija. Kai kuriems nustatytas kulkšnies-žasto indeksas, esant indikacijų - atlikta galvos kompiuterinè tomografija, magnetinio rezonanso tomografija. Statistinių duomenų vidurkių skirtumai vertinti Stjudento (Student) patikimumo kriterijumi t. Skirtumai laikyti statistiškai patikimi, kai $\mathrm{p}<0,05$.

Rezultatai. Išanalizuoti galvos smegenų kraujotakos sutrikimai, sergant periferinių arterijų liga. Praeinantis smegenu išemijos priepuolis buvo $9(32,1 \%)$ ligoniams, išeminis insultas $-5(17,9 \%)$, išeminio insulto padariniai - 14(50,0\%). Nustatyta, kad, įvykus praeinančiam galvos smegenų išemijos priepuoliui, fibrinogeno ir C-reaktyvinio baltymo koncentracija kraujo serume nebuvo padidejusi - atitinkamai 3,62 $\pm 0,06$ $\mathrm{g} / 1$ ir $1,82 \pm 1,31 \mathrm{mg} / 1$. Išeminio insulto atveju fibrinogeno kiekis kraujo serume buvo 5,25 $\pm 0,8 \mathrm{~g} / 1$, sergančiųjų lètine galvos smegenų išemija - 2,18 $\pm 0,35$ $\mathrm{g} / 1(\mathrm{p}<0,02)$. C-reaktyvinio baltymo kiekis kraujo
\end{abstract}

serume, ịvykus išeminiam insultui, buvo $70,67 \pm 41,11$ $\mathrm{mg} / \mathrm{l}$, sergančiujų lètine galvos smegenų išemija $2,02 \pm 0,43 \mathrm{mg} / \mathrm{l}(\mathrm{p}>0,05)$. Kulkšnies-žasto indeksas ūminiu išeminio insulto periodu buvo $0,46 \pm 0,27$. Praeityje išeminị insultą patyrusių ligonių fibrinogeno kiekis kraujo serume buvo 4,92 $\pm 0,65 \mathrm{~g} / 1$, sergančiujuc lètine galvos smegenų išemija $-2,18 \pm 0,35 \mathrm{mg} / \mathrm{l}$ (p $<0,01)$. C-reaktyvinio baltymo kiekis patyrusiems išeminị insultą praeityje buvo 57,99 $\pm 36,05 \mathrm{mg} / \mathrm{l}$, sergančiujų lètine galvos smegenų išemija $-2,02 \pm 0,43$ $\mathrm{mg} / \mathrm{l}(\mathrm{p}>0,05)$. Pateikti klinikiniai atvejai. Apžvelgta naujausia mokslinè literatūra apie periferinių arterijų ligą ir išeminị insultą, šių ligų derinị.

Išvados. 1. Periferinių arterijų liga yra išeminio insulto rizikos veiksnys. Ji dažnai susijusi su išeminiu insultu. 2. Išeminio insulto atveju ir patyrus išemini insultą praeityje, sergančiųų periferinių arterijų liga fibrinogeno koncentracijos kraujo serume padidejimas, palyginus su lètine galvos smegenų išemija sergančiųjų grupe, yra statistiškai patikimas. 3. Žemas kulkšnies-žasto indeksas rodo subklinikinę periferinių arterijų ligą ir insulto riziką. Esant asimptominei periferinių arterijų ligai, išeminio insulto prevencijai turi būti skiriami antiagregantai. 4. Išeminio insulto atveju sergančiujų periferinių arterijų liga kulkšniesžasto indeksas yra ženkliai sumažejęs ir atskleidžia didelę kartotinio insulto ir kraujagyslinių įvykių riziką. Kulkšnies-žasto indekso nustatymas patyrusiems išeminį insultą gali padèti atrinkti didelès rizikos ligonius, kuriems turi būti taikoma antrinè insulto prevencija.

\section{Ivadas}

Aterosklerozè yra plačiai paplitusi lètinè progresuojanti liga. Klinikoje ji pasireiškia išemine širdies, cerebrovaskuline ir periferinių arterijų liga (PAL). Rizikos vertinimo lentelès, uždegiminiai žymenys, vizualiniai tyrimai, kulkšnies-žasto indekso (KŽI) nustatymas gali padèti diagnozuoti subklinikinę aterosklerozę [1,2]. Endotelio disfunkcija (ED) yra esminis dalykas aterosklerozès formavimosi procese. Jos 
buvimas yra klinikinių ịvykių rizikos veiksnys ir gali būti aterosklerozès sunkumo žymeniu. ED gali būti vertinama nustatant mikroalbuminuriją, trombocitų funkcijas, C-reaktyvinį baltymą (CRB). ED nustatyta insultą patyrusiems ligoniams ir yra susijusi su insulto patofiziologija, potipiais, klinikiniu sunkumu ir baigtimis. KŽI taip pat yra generalizuotos aterosklerozės žymuo, o sumažėjęs KŽI susijęs su padidèjusiu insulto pasireiškimu vyresnio amžiaus žmonèms [3]. Kuo žemesnis KŽI, tuo didesnè miokardo infarkto ir insulto rizika [4]. Sergant aterosklerozinemis ligomis (MI, insultu, PAL), vienas iš pagrindinių procesų yra fibrino krešulio susidarymas. Fibrinas susidaro iš cirkuliuojančio pirmtako fibrinogeno, veikiant trombinui. Epidemiologiniai tyrimai parodè šio hemostazinio baltymo reikšmę širdies ir kraujagyslių ligų atsiradimui. Fibrinogeno kiekio nustatymas gali būti naudingas asimptominių širdies ir kraujagyslių ligų diagnostikai [5]. PAL yra sisteminès aterosklerozès manifestacija. Ji laikoma pažengusios aterosklerozės žymeniu [6]. PAL pažeidžia 4-12\% 55-70 metų žmonių ir 20\% žmonių, vyresnių nei 70 metų [7]. Sergančiųų PAL kognityvinès funkcijos yra blogesnès [8]. PAL serga 8-12 milijonų amerikiečių, iš jų 15-40\% pasireiškia protarpinis šlubumas, ribojantis kasdienę veiklą [9]. Protarpinis šlubumas yra pagrindinis PAL simptomas, jo paplitimas tarp sergančiujų PAL yra nuo 4,5\% iki 54,4\% [10]. PAL simptomai svyruoja nuo protarpinio šlubumo iki kritinès išemijos ir galūnès amputacijos. Nepaisant to, kad protarpinis šlubumas pripažintas pagrindiniu aterosklerozės rizikos veiksniu, daugeliu atvejų PAL lieka nediagnozuota. Asimptominė PAL, kurią rodo sumažėjęs KŽI, turètų įspèti klinicistus apie aterotrombozinę ligą ir jos gydymą. PAL būdinga periferinių arterijų stenozè ir okliuzija [11]. Periferinių arterijų okliuzinè liga (PAOL) yra sudetingiausia angiologijos problema. Šios ligos paplitimas yra $2 \%$ tarp vyrų iki 50 metų ir 5\% tarp vyrų, vyresnių nei 70 metų. Moterys pasiekia tuos pačius skaičius maždaug po 10 metų [12]. PAL sunkumas koreliuoja su padidèjusia MI, insulto ir kardiovaskulinès mirties rizika [13]. PAL sergantiems ligoniams būdingas didelis mirtingumas nuo širdies ir kraujagyslių ligų [14]. Sergančiujų PAL pagrindinès mirties priežastys yra MI ir insultas [15]. KŠL yra dažniausia sergančiųjų PAOL mirties priežastis (40-60\%). Išeminis insultas būna $10-20 \%$ ligonių mirties priežastis. Apie $10-20 \%$ ligonių miršta dèl nekardialinių veiksnių [12].

Darbo tikslas - išanalizuoti sergančiujų PAL galvos smegenų kraujotakos sutrikimus, atkreipiant dèmesị $i$ išeminio insulto ir PAL ryšs̨i.

\section{Tyrimo medžiaga ir metodai}

Vilniaus miesto klinikinès ligoninès Kraujagyslių chirurgijos, Invazinès radiologijos ir endoprotezavimo skyriuose bei Anesteziologijos angiochirurgijos reanimacijoje 2017 m. vasarị - $2019 \mathrm{~m}$. birželị tyrème 28 ligonius (10 moterų, 18 vyrų), kurie sirgo PAL ir galvos smegenų kraujotakos sutrikimais. Ligonių amžius - 49-87 metai (vidurkis 73,2 $\pm 1,9$ metų). Vidutinè stacionarinio gydymo trukmè - 7,7 dienos. Palyginamają grupę sudare 11 lètine galvos smegenų išemija (LGSI) sergančių asmenų. Visi ligoniai konsultuoti neurologo ir angiochirurgo (straipsnio autorių). Jiems nustatyta diagnozé, skirtas gydymas. Visiems ligoniams atliktas bendrasis ir biocheminis kraujo tyrimas (fibrinogeno, CRB koncentracija kraujo serume, lipidograma), elektrokardiograma, ultragarsinis kojų kraujagyslių tyrimas, konvenciné arteriografija, kai kuriems nustatytas KŽI, esant indikacijų - atlikta galvos kompiuterinè tomografija (KT), magnetinio rezonanso tomografija (MRT). Statistinių duomenų vidurkių skirtumai vertinti Stjudento patikimumo kriterijumi $t$. Skirtumai laikyti statistiškai patikimi, kai $p<0,05$.

\section{Rezultatai}

Praeinantis smegenų išemijos priepuolis (PSIP) pasireiškė 9(32,1 proc.) ligoniams. Fibrinogeno ir CRB koncentracija kraujo serume, ivvykus PSIP, nebuvo padidejusi - atitinkamai 3,62 $\pm 0,06 \mathrm{~g} / \mathrm{l}$ ir 1,82 $\pm 1,31 \mathrm{mg} / \mathrm{l}$.

Ligonis B. C., 70 metų, hospitalizuotas dèl dešiniosios kojos skausmo einant, šlubumo, galvos svaigimo, trumpalaikio sąmonès netekimo. Objektyviai: AKS - 140/70 mmHg, P - 67 k./min., protarpinis šlubumas dešine koja, neskausminga distancija apie 100 metrų. Neurologinis tyrimas: abipusis konvergencijos silpnumas, nežymūs statinès ataksijos reiškiniai, sausgysliniai refleksai $\mathrm{d}=\mathrm{s}$, patologinių refleksų neišgauta, Marinesku-Radovičiaus refleksas kairejje. Tyrimai: leuk. 10,58 $10^{9} / 1$, eritr. 3,94·10 $12 / 1$, Hb 120 g/l, hematokr. $34,7 \%$, tromb. $197 \cdot 10^{9} / 1$, neutr. $79,2 \%$, limf. $14,2 \%$, mon. $5,9 \%$, eoz. $0,5 \%$, baz. $0,2 \%$; ADP (klopidogrelis ir kt. testas) 49 U, ASPI (aspirino testas) 50 U. Dešiniosios kojos arteriju dvigubas sonoskopinis skenavimas: trombas a.poplitea dex. III segmente. Konvencinè dešiniosios kojos arteriografija: užakusi a.poplitea, stenozuotos a.tibialis anterior, a.tibialis posterior ir a.peronea. Ekstrakranijinių kraujagyslių ultragarsinis dvigubas skenavimas: galima įtarti ACI sin. hemodinamiškai reikšmingą stenozę; ACI dex. stenozè mažiau 40\%; AV dex. hipoplazija. Kaklo, pečiu juostos KT su angiografijos programa: ACI dex. C3-C7 segmentų stenozès 50-70\%; ACE dex. stenozès iki 30\%; AV dex. hipoplastiška, ryški V4 segmento hipoplazija; ACI sin. proksimalinès dalies stenozės iki 70\%. AV sin.V4 segmento stenozės iki 70\%. Atlikta galvos MRT: ūmių patologinio tankio židininių pokyčių nematyti, involiuciniai galvos smegenų pakitimai. Diagnozè - PAL. Užakusi dešinioji pakinklinè arterija. Lètinè dešiniosios kojos išemija, Fontaine II B stadija. Būklè po revaskuliarizacijos. LGSI. PSIP vertebrobaziliniame baseine. Gydymas: a.poplitea dex. endarterekto- 


\section{4}

mija, AFS dex. distalinio segmento bei a.poplitea dex. III segmento plastika; antibiotikai, infuzoterapija, heparinas, antiagregantai (kadangi ADP testas neigiamas, klopidogrelio skyrimas nutrauktas), vinpocetinas, mildronatas, eufilinas. Rekomendacijos išrašant: vaikščiojimo terapija, aspirinas, cilostazolis, atorvastatinas.

Išeminis insultas ịvyko 5(17,9 proc.) ligoniams. Išeminio insulto atveju fibrinogeno koncentracija kraujo serume buvo $5,25 \pm 0,8 \mathrm{~g} / 1$, sergančiųjų LGSI - 2,18 $\pm 0,35 \mathrm{~g} / 1$ $(p<0,02)$. CRB koncentracija kraujo serume, ivvykus išeminiam insultui, buvo $70,67 \pm 41,11 \mathrm{mg} / 1$, sergančiųjų LGSI $-2,02 \pm 0,43 \mathrm{mg} / \mathrm{l}(\mathrm{p}>0,05)$. KŽI ūminiu išeminio insulto periodu buvo $0,46 \pm 0,27$.

Ligonis I. T., 64 metų, hospitalizuotas skubos tvarka dèl dešiniosios kojos nuovargio, šlubumo. Praeityje atliktas aortos bifurkacinis ir femorofemoralinis šuntavimas. Nustatyta, kad aortos bifurkacinis protezas ir femorofemoralinis šuntas trombuoti, yra subrenalinè aortos okliuzija, tačiau kojos kraujotaka kompensuota. Skirtas medikamentinis gydymas. Atsiradus dešiniosios rankos tirpimui, tirtos kaklo kraujagyslès. Kaklo kraujagyslių dvigubas ultragarsinis skenavimas: ACI sin. stenozė 70-90\% (greitis 2,5/0,8 m/s lokaliai), ACI dex. ilga plokštelè, stenozė 70-90\% (greitis 2,2/0,5 m/s), abiejų AV stenozès $<50 \%$. Kaklo, pečių juostos KT su angiografijos programa: dauginès brachiocefalinių arterijų stenozès. Insulto prevencijai ligonis operuotas - atlikta kairiosios ACI endarterektomija. Pirmają pooperacinę dieną ligoniui pradèjo svaigti galva, nutirpo dešinioji ranka ir koja. Neurologinis

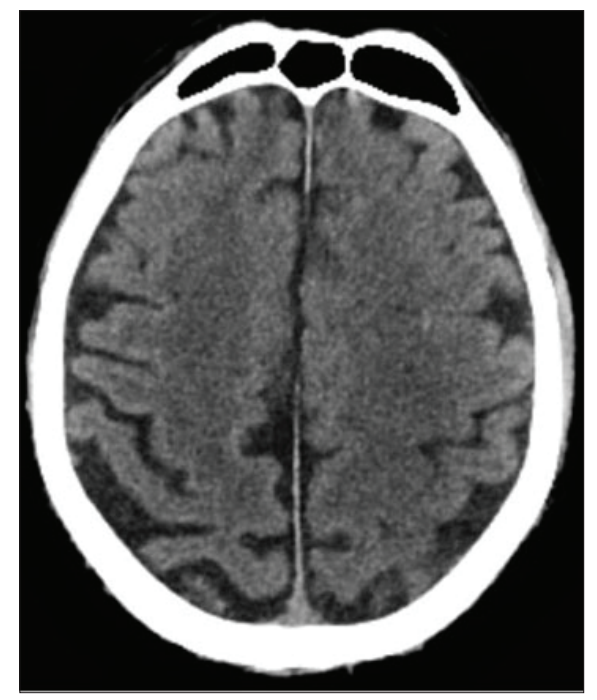

1 pav. Ligonio L.T. galvos KT: kairès frontalinès skilties gyrus precentralis srityje nežymiai sumažèjusi žievès ir požievio diferenciacija, kiek palyginti subarachnoidiniai tarpai - ūmios išemijos požymiai. tyrimas: kairiosios akies konvergencijos silpnumas, dešiniųų galūnių hipestezija, gili dešiniosios rankos parezè, dešiniosios kojos parezè, sausgysliniai refleksai $\mathrm{d}>\mathrm{s}$, Babinskio refleksas dešinèje. Atlikta galvos KT (1 pav.). Tyrimai: leuk. $11,47 \cdot 10^{9} / 1$, eritr. $5,55 \cdot 10^{12} / 1, \mathrm{Hb} 171 \mathrm{~g} / 1$, hematokr. 49,8\%, tromb. $248 \cdot 10^{9} / 1$, SPA $92 \%$, fibrinog. 3,69 g/l, gliuk. 6,42 mmol/l, CRB 62,25 mg/l, K 4,58 mmol/l, Na 137 mmol/1, ASPI 40 U, ADP 45 U. Diagnozè - PAL. Lètinè kojų išemija. Aortos bifurkacinio protezo ir femorofemoralinio šunto trombozè. Būklè po ACI sin. endarterektomijos. Išeminis insultas ACM sin. baseine: dešinioji hemiparezė. Gydymas: atlikta ACI sin. endarterektomija ir plastika, infuzoterapija, cefuroksimas, klopidogrelis, pentoksifilinas, eufilinas, mildronatas, heparinas, vèliau - aspirinas.

Ligonis J.T., 70 metų, skundèsi kairiosios pèdos skausmu, šlubumu. Praeityje atlikta dešiniosios blauzdos amputacija, kairiosios blauzdos revaskuliarizacija. Serga PAH, CD, LIL. Objektyviai: kairioji peda pamėlusi, patinusi, skausminga. AKS 140/90 mmHg, P 73 k./min. Tyrimai: leuk. 16,22 $10^{9} / 1$, eritr. 3,42 $10^{12} / 1, \mathrm{Hb} 100 \mathrm{~g} / \mathrm{l}$, hematokr. $30,7 \%$, SPA $80 \%$, fibrinog. 7,4 g/l, CRB 234,72 mg/l, šlapalas 12,2 mmol/1, kreatininas $121 \mu \mathrm{mol} / \mathrm{l}$, GFG $51 \mathrm{ml} / \mathrm{min} . / 1,73 \mathrm{~m}^{2}$, gliuk. 12 $\mathrm{mmol} / \mathrm{l}$, ADP $58 \mathrm{U}, \mathrm{K} 5,25 \mathrm{mmol} / \mathrm{l}$, Na $137 \mathrm{mmol} / \mathrm{l}$. EKG: KSH požymiai, išemijos žymès apatinèje ir šoninèje sienelèse. Krūtinès ląstos rentgenografija: dešiniojo plaučio pneumonija, hidrotorakso požymiai, KMP, aortos dilatacija, sklerozė. Atlikta a.tibialis sin. rekanalizacija, kairiosios kojos

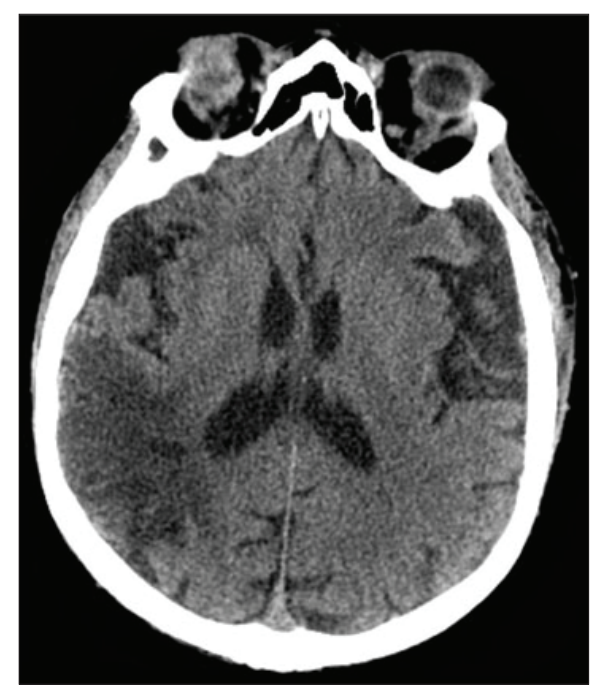

2 pav. Ligonio J.T. galvos KT: išemijos zona smilkininèje, pakaušinèje, momeninèje skiltyse dešinejje; konveksitaliniai subarachnoidiniai tarpai šioje srityje išlyginti; abipus periventrikuliariai - neaiškių ribų švelniai hipodensinès zonos. 
būklei negerèjant - kairiosios blauzdos amputacija. Blogèjant bendrajai būklei, ligonis tapo vangus, mieguistas. Neurologinis tyrimas: soporas, intoksikacija, viršantakiniai, junginès, ragenos refleksai susilpnėję, i skausmą reakcija išlikusi, itariama kairiosios rankos parezè, sausgysliniai refleksai s $>$ d rankose. Galvos KT (2 pav.). Diagnozè: kojų arterijų aterosklerozè, protarpinis šlubumas ir gangrena. 2 tipo $\mathrm{CD}$, periferinè angiopatija. Būklè po dešiniosios ir kairiosios blauzdų amputacijos. Hipertenzinè širdies liga su ŠN. LIL, 3 stadija. Išeminis insultas ACM dex. ir ACP dex. baseine: kairioji hemiparezė. Gydymas: kairiosios blauzdos amputacija; vankomicinas, deksketoprofenas, heparinas, aspirinas, eufilinas, mildronatas, deksametazonas, furozemidas, paskutinę parą - noradrenalinas. Progresavo širdies, kvejpavimo ir inkstų funkcijos nepakankamumas. Ligonis mirè.

Išeminio insulto padariniai buvo 14 (50,0 proc.) ligonių. Praeityje patyrusių išeminį insultą ligonių fibrinogeno koncentracija kraujo serume buvo 4,92 $\pm 0,65 \mathrm{~g} / 1$, sergančiujų LGSI - 2,18 $\pm 0,35 \mathrm{~g} / 1(\mathrm{p}<0,01)$. CRB koncentracija kraujo serume buvo $57,99 \pm 36,05 \mathrm{mg} / 1$, sergančiųjų LGSI - 2,02 $\pm 0,43$ $\mathrm{mg} / \mathrm{l}(\mathrm{p}>0,05)$.

Ligonis R. V., 67 metų, hospitalizuotas dèl kairiosios kojos šalimo ir skausmo. Praeityje atlikta AIE sin. angioplastika ir stentavimas, AFS sin. endarterektomija ir protezo plastika, AIE dex. stenozių angioplastika, femoropoplitinio protezavimo operacija dešiniojoje kojoje, AFP sin. angioplastika. Objektyviai: pulsas apčiuopiamas abiejose kirkšnyse, kairiosios kojos trofikos sutrikimų nèra, jutimas nesutrikęs, kontraktūrų nèra, tačiau skausmingi blauzdos raumenys. Ligonis praeityje patyre išeminị insultą. Neurologinis tyrimas: abipusis konvergencijos silpnumas, dešiniųjų galūnių hipes- tezija, sausgysliniai refleksai $\mathrm{d}>\mathrm{s}$, provokuojasi Babinskio refleksas dešinèje, Marinesku-Radovičiaus refleksas kairèje, kognityvinė disfunkcija. Galvos KT (3 pav.). Kaklo, pečių juostos KT su angiografijos programa: ACC dex., ACI dex. trombozè, trombuotas ACI dex. stentas, ACE dex., ACE sin. žiočių okliuzija, ACI sin. C1 segmento stenozė 3045\%, C3-C6 segmentų stenozès iki 50-70\%, AV sin. žiočių proksimalinès dalies stenozė $30-50 \%$, tr. brachiocephalicus, a.subclavia dex. stenozès iki 30-50\%. EKG: ūmios išemijos požymiai skilvelių miokarde, randiniai pakitimai apatinèje sienelëje. Sirdies echoskopija: kairiajame skilvelyje stebimas priesieninis $1,5 \times 1 \mathrm{~cm}$ diametro trombas. Tyrimai: leuk. $6,61 \cdot 10^{9} / 1$, eritr. $4,75 \cdot 10^{12} / 1, \mathrm{Hb} 147 \mathrm{~g} / 1$, hematokr. 43,6\%, tromb. $145 \cdot 10^{9} / 1$, SPA $76 \%$, fibrinog. $4,16 \mathrm{~g} / 1$, d-dimerai $1,26 \mu \mathrm{g} / \mathrm{ml}$, gliuk. $4,84 \mathrm{mmol} / \mathrm{l}$, CRB 11,64 mg/1, ADP 20 U, ASPI 27 U, K 4,59 mmol/l, Na $140 \mathrm{mmol} / \mathrm{l}$. Diagnozè PAL. AFC sin. embolija. Funkcionuojantis AIE sin. stentas. Užakusios AFS sin., a.poplitea sin., a.tibialis sin. Ūminè kairiosios kojos išemija, IIa kategorija. Būklè po AFC sin. embolektomijos. KŠL. Ūminis Q (-) priekinis-šoninis MI. Trombas KS viršūnèje. PAH II ${ }^{0}$. Cerebrovaskulinè liga. ACI dex. stento užakimas. Išeminio insulto padariniai: dešinysis hemisindromas. Vainikinių arterijų šuntavimas bei trombo iš širdies kamerų pašalinimas nebuvo atliktas dèl ACI dex. stento užakimo. Paskirtas antitrombozinis gydymas. Atlikta AFC sin. embolektomija ir trombektomija. Esant didelei AIE sin. stento trombozès rizikai, nuspręsta atlikti kairiosios kojos revaskuliarizaciją. Operacijos metu rastas aortos lanke užakęs ACI dex. stentas iki C7 segmento - revaskuliarizacija negalima, gydymas medikamentinis. Kairiosios kojos revaskuliarizacija atlikta vietineje nejautroje - atkurta

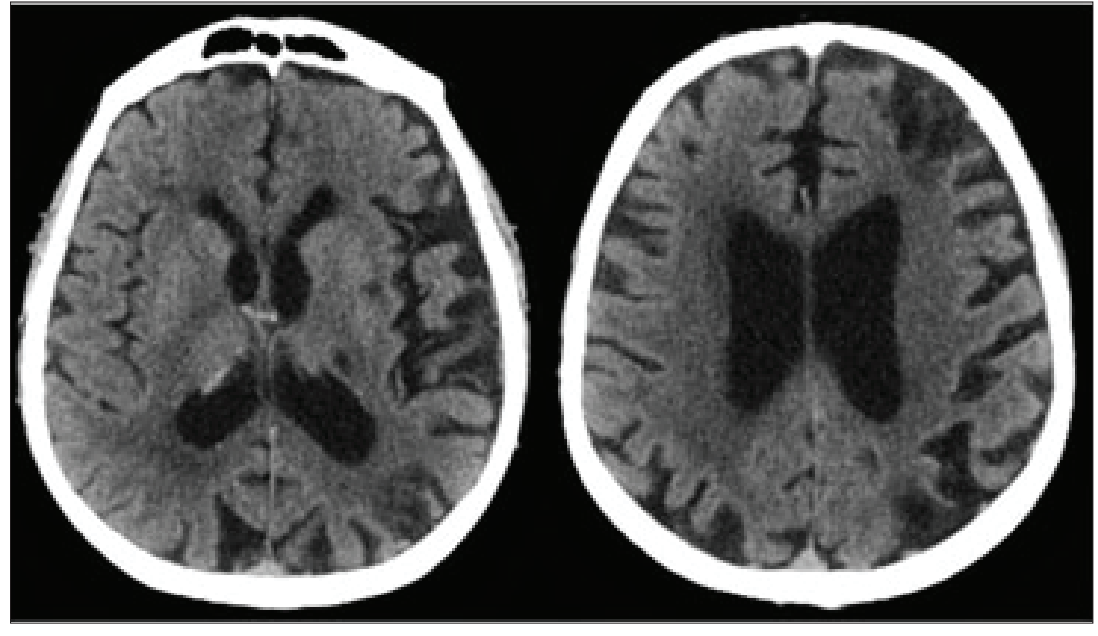

3 pav. Ligonio R.V. galvos KT: poišeminės encefalomaliacijos zonos kairèje kaktinėje ir momeninèje skiltyse; smulkūs poišeminiai židinukai pamato branduolių srityje; abipus paraventrikuliariai, subkortikaliai - neaiškių ribų švelniai hipodensinės zonos.

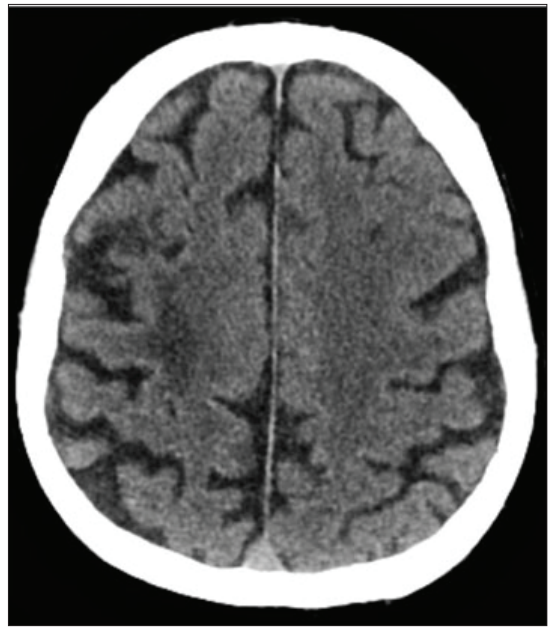

4 pav. Ligonio S.D. galvos KT: poišeminè encefalomaliacijos zona dešinèje kaktinèje skiltyje. 
kraujotaka i APF sin. Pagerèjus kojos kraujotakai, išnyko skausmai. Rekomendacijos ligoni išrašant: aspirinas, klopidogrelis, orfarinas, ligonio slauga, pakartotina kardiochirurgo konsultacija.

Ligonis S.D., 62 metų, pakartotinai hospitalizuotas dèl pasikartojusio dešiniosios kojos protarpinio šlubumo (neskausminga distancija apie 50 metrų), galvos skausmo ir svaigimo. Praeityje atlikta AIE sin., AFS dex. endovaskuliné balionizacija (PTA), AFC sin. endarterektomija, kairiosios kojos femoropoplitinis šuntavimas, del poraktikaulinio nuvogimo sindromo atliktas kairiosios pusés kortikosubklavinis protezavimas, rekonstruota ACI sin., stentuotas tr. brachiocephalicus. Objektyviai: AKS-180/90 mmHg, P-60 k./min., kojose trofikos sutrikimų nestebima, kaireje pulsas apčiuopiamas ADP sin., dešinejje - tik AFC dex. Neurologinis tyrimas: hipestezija kairiosiose galūnèse, sausgysliniai refleksai $\mathrm{s}>\mathrm{d}$, patologinių refleksų neišgauta, Marinesku-Radovičiaus refleksas kaireje. Tyrimai: leuk. $4,81 \cdot 10^{9} / 1$, eritr. $5,05 \cdot 10^{12} / 1$, $\mathrm{Hb} 168 \mathrm{~g} / \mathrm{l}$, hematokr. $48,2 \%$, tromb. $174 \cdot 10^{9} / 1$, SPA $100 \%$, fibrinog. 2,63 g/l, gliuk. 4,7 mmol/l, CRB 0,51 mg/l, K 5,02 $\mathrm{mmol} / \mathrm{l}, \mathrm{Na} 141 \mathrm{mmol} / \mathrm{l}$. Ekstrakranijinių kraujagyslių ultragarsinis dvigubas skenavimas: ACC dex. stenozè $>70 \%$, ACI dex. stenozè apie $90 \%$, ACC sin. stenozè $>50 \%$, ACI sin. stenozè $50-70 \%$, abiejų AV stenozè $>50 \%$, karotikosubklavinis šuntas kairejje funkcionuoja. Galvos KT (4 pav.). Konvencinè dešiniosios kojos arteriografija: stenozuotos AIC, AIE, AFC, AFS $>50 \%$, blauzdos arterijos; užakusi AII. EKG: KSH, antrinis repoliarizacijos sutrikimas šoninèje sienelèje, galimi randiniai pakitimai apatinèje sienelèje. Diagnozè - PAL. AIC dex. ir AFS dex. stenozès. Kritiné AFC dex. stenozè. Lètinè dešiniosios kojos išemija, Fontaine II B stadija. Būklè po AIC dex. stentavimo ir AFC dex. endarterektomijos. Cerebrovaskuliné liga. ACC dex. ir sin., ACI dex. stenozès. Funkcionuojantis tr. brachiocephalicus ir kairysis karotikosubklavinis protezas. Išeminio insulto padariniai: kairysis hemisindromas. Gydymas: atlikta AIC dex. stenozès PTA, implantuotas stentas; AFS dex. stenozès PTA; AFC dex. atvira endarterektomija, jos bifurkacijos plastika; infuzoterapija, cefuroksimas, heparinas, aspirinas, klopidogrelis, eufilinas, pentoksifilinas, vinpocetinas.

Dèl PAL dauguma ligonių gydyti angiochirurginiu būdu (endarterektomija, šuntavimas, protezavimas, angioplastika, stentavimas, amputacija), kitiems atlikta PTA. Visiems skirtas ir medikamentinis gydymas (antikoaguliantai, antiagregantai, statinai, vazodilatatoriai, nootropai, antibiotikai ir kt.). Mirè 3(10,7\%) ligoniai (ūmus kardiopulmoninis nepakankamumas, insultas).

\section{Rezultatų aptarimas}

PAL susijusi su vainikinių arterijų liga (VAL) ir išeminiu insultu, tačiau duomenų apie PAL ir išeminio insulto ryši yra mažai. Tirtas 101 ligonis, pirmą kartą patyręs išeminị insultą. Visiems atlikta galvos MRT, miego arterijų ultrasonografija ir transtorakalinè echokardiografija. Ligonių amžius - 41-92 metai. PAL buvo 81 ligoniui $(80,2 \%)$, iš jų $57(78,1 \%)$ - nedidelè arterijų okliuzija, $11(84,6 \%)$ - didelè arterijų okliuzija ir 13(86,7\%) - kardiogeninè embolija. PAL buvo asimptomine 42(51,9\%) ligoniams. Sergantiesiems PAL nustatytas didesnis serumo apoproteino A1 kiekis. Jiems buvo reikšmingai didesnis modifikuotas Rankino skalès balas. Apoproteino A1 kiekis ir modifikuotas Rankino skalès balas hospitalizacijos metu huvo glaudžiai susieti su išeminio insulto atsiradimu. Studijos duomenys rodo, kad PAL dažnai susijusi su ūminiu išeminiu insultu. Patyrusiems išeminį insultą ligoniams svarbu atlikti PAL tyrimą [16]. Mūsų pateiktas 67 metų ligonio R. V. klinikinis atvejis vaizdžiai atskleidžia glaudų visų trijų aterosklerozès klinikinių apraiškų (MI, išeminio insulto ir PAL) tarpusavio ryšį ir aterosklerozinio proceso generalizaciją. 64 metų ligoniui I. T. pirmiausia pasireiškè PAL klinika, po to - insulto simptomatika. Šių ligų klinika papildè viena kitą - pirmiausia ligonis pajuto dešiniosios kojos skausmą, šlubumą, po to - dešiniosios kojos ir rankos tirpimą, silpnumą, - ryškèjo insulto klinika.

Tirti 142 išeminiu insultu ir protarpiniu šlubumu sergantys ligoniai. Išeminis insultas ligoniams, kuriems pasireiškẻ protarpinis šlubumas, sudare $7,7 \%$ nuo visų išeminių insultų. Išeminiu insultu sergančių ligonių su protarpiniu šlubumu ir be protarpinio šlubumo hospitalinis mirtingumas buvo panašus (atitinkamai 16\% ir 14\%), funkcijų apribojimas panašus $(20,5 \%$ ir $18,5 \%)$. KŠL, PSIP, IFN buvo reikšmingi nepriklausomi prognostiniai išeminio insulto rizikos veiksniai, esant protarpiniam šlubumui. Nors protarpinio šlubumo atvejais išeminio insulto klinika išreikšta, prognozė panaši kaip išeminio insulto, nesant protarpinio šlubumo [17].

Duomenys apie PAL, kaip būsimojo insulto rizikos veiksnị, yra prieštaringi. Siekiant kiekybiškai ịvertinti sergančiujų PAL rizikos padidejjimą sergamumui ir mirtingumui dèl insulto, tirti 688065 metų ir vyresni ligoniai. Penkerių metų laikotarpiu stebėti kraujagysliniai įvykiai ir mirties atvejai. PAL diagnozuota, kai KŽI buvo $<0,9$ arba atlikta periferinè revaskuliarizacija, galūnės amputacija ar pasireiškè protarpinis šlubumas. Penkerių metų laikotarpiu insultas įvyko 183 ligoniams. Žemesnis KŽI buvo susijęs su didesne insulto rizika. PAL buvo reikšmingas nepriklausomas išeminio insulto rizikos veiksnys [18]. Nustatytas ryšys tarp PAL ir insulto atsiradimo, esant ribinei PAL. Tirtas insulto pasireiškimas visame KŽI spektre: KŽI $<0,90 ; 0,90-0,99$; 1,00-1,09; >1,3. Iš 6382 tirtų suaugusių asmenų $277(6 \%)$ ivvko insultas. Patyrę insultą asmenys buvo vyresni ir sirgo $\mathrm{CD}$, hipertenzija, KŠL , jiems buvo padidèjęs glikuotas hemoglobinas. Nustatyta, kad insultas dažnesnis ligoniams, 
kurių KŽI $<0,9$ ar $=0,9(12,7 \%$ ir 5,4\%, p<0,001). Insultas dažnėja, mažejjant KŽI. KŽI lygis $<0,9$ ir 0,9-0,99 susijęs su insulto pasireiškimu [19]. Siekta nustatyti ryši tarp PAL, KŠL ir insulto rizikos ligoniams, sergantiems 2 tipo CD. Tirti 1178 CD sergantys ligoniai. Jie suskirstyti ị dvi grupes: PAL grupę (KŽI $<0,9$ arba $>1,4 ; 88$ ligoniai, $7,5 \%$ ) ir ne PAL grupę (KŽI $>0,9$ ir $\leq 1,4 ; 1090$ ligonių, $92,5 \%$ ). PAL grupejje buvo daug didesnè mirtino insulto rizika $(\mathrm{p}<0,05)$. Logistinè laipsniškos regresijos analizé parodè, kad KŽI buvo nepriklausomas prognostinis KŠL ir insulto rizikos veiksnys 2 tipo CD sergantiems ligoniams [20]. Tirti 327 ligoniai. Vidutinis amžius $-57,6 \pm 12,8$ metų. PAL nustatyta 60(18,3\%) ligonių. PAL buvo 32(17,5\%) ligoniams, esant lengvai miego arterijų stenozei ir $25(17,8 \%)$ ligoniams, esant vidutinei miego arterijų stenozei. Neįprastai žemas KŽI, rodantis subklinikinę PAL, buvo $18 \%$ ligonių [21]. PAL, kaip generalizuotos aterosklerozès žymens nustatymas po ūminio išeminio insulto ar PSIP, gali pagerinti būsimų aterotrombozinių komplikacijų prevenciją. Vertintas PAL paplitimas ligoniams, sergantiems išeminiu insultu ar PSIP. Tirti 759 ligoniai, 55,8 \% tiriamųų buvo vyrai. 739 (97,4\%) nustatytas KŽI. Vidutinis ligonių amžius buvo $69,5 \pm 12,1$ metų. $81,6 \%$ ligonių sirgo ūminiu išeminiu insultu, $18,4 \%$ - PSIP. Tik 6,2\% sirgo PAL, tačiau KŽI $\leq 0,9$ buvo $44,9 \%$ ligonių. Ligoniai, kurių KŽI $\leq 0,9$, buvo vyresni ir sirgo PAL, hipertenzija, CD, staziniu širdies nepakankamumu. KŽI $\leq 0,9$ statistiškai reikšmingai susijęs su miego arterijų stenoze $>50 \%$ ir Eseno insulto rizikos laipsniu $>2$. Tai rodo, kad insulto pasikartojimo rizika vienerių metų laikotarpiu yra 4\%. Daugeliui ligonių, sergančių ūminiu išeminiu insultu ar PSIP, yra subklinikinė PAL [22]. 79 ligoniams atliktas klinikinis ir ultrasonografinis tyrimas (20 ligoniu sirgo PSIP, 59 - išeminiu insultu). Visiems ligoniams dopleriu nustatytas KŽI (KŽI $\leq 0,9$ vertintas kaip sumažejęss). Žemas KŽI buvo $16(20,3 \%)$ ligonių. KŽI $\leq 0,9$ buvo susijęs su hipertenzija, rūkymu, hipercholesterolemija, KŠL, ankstesne PAL, vyriška lytimi, vidinès miego arterijos stenoze $>50 \%(p<0,10)$. Išeminiu insultu sergantiems ligoniams dažnesnis žemas KŽI. Asimptominė PAL rodo sergančiųjų išeminiu insultu aterosklerozès išplitimą. KŽI nustatymas yra svarbus adekvačiai prevencinei terapijai [23]. Tirtas 101 insultą patyręs ligonis, nustatytas KŽI. PAL diagnozuota, kai KŽI buvo $<0$,9. Pakitęs KŽI nustatytas 19(18,8\%) ligonių. 11 ligonių buvo asimptominiai, 8 pasireiškè protarpinis šlubumas. Sergančiujų PAL lytis, hipertenzijos paplitimas, dislipidemija, alkoholio vartojimas nesiskyrè, kaip ir nesant PAL. Sergamumas CD $(63,6 \%)$ buvo didesnis sergančiųjų PAL. PAL paplitimas buvo didesnis tarp sergančiujų aterotromboziniu insultu. PAL buvo 18,8\% insultu sergančiu ligonių. Asimptominè PAL diagnozuota beveik 60\% ligonių. Asimptominès PAL paplitimas buvo didesnis tarp CD ir insultu sergančių ligonių
[24]. Išeminį insultą patyrusiems ligoniams asimptominès VAL paplitimas svyravo nuo $25 \%$ iki $60 \%$. PAL diagnozuota $10 \%$ ligonių. MI rizika buvo apie $2 \%$ per metus, kraujagyslinè mirtis $-2 \%$ per metus [25].

Tirtas VAL, išeminio insulto ir PAL paplitimas vyresnio amžiaus žmonėms. Tirti 474 vyrai ir 1328 moterys, kurių amžius $80 \pm 9$ metai (nuo 60 iki 102 metų). Iš 1802 ligonių 612 (34\%) buvo VAL, 351 (19\%) - išeminis insultas, 236 (13\%) - PAL. Duomenys parodè, kad, esant VAL, išeminis insultas buvo $32 \%$, o PAL - 26\% ligonių. Išeminio insulto atveju VAL buvo 56\%, PAL - 28\% ligonių. Sergant PAL, 68\% ligonių buvo VAL, 42\% - išeminis insultas [26]. Analizuoti KŽI pokyčiai 747 išeminiu insultu ir PSIP sergantiems ligoniams, vertinta KŽI koreliacija su insulto rizikos veiksniais ir insulto potipiais. KŽI sumažèjimas $(\leq 0,9)$ buvo $18,1 \%$ tarp sergančiųjų išeminiu insultu. Pakitęs KŽI sergant išeminiu insultu koreliavo su moteriška lytimi, amžiumi ( $\geq 60$ metų) ir ankstesniais išeminiais įvykiais: VAL, cerebrovaskuline liga ir prieširdžių virpejjimu (PV). Išeminiu insultu sergantiems ligoniams reikia nustatyti KŽI, siekiant diagnozuoti asimptominę PAL ir rizikos veiksnius, susijusius su kartotinu insultu ir kitais kraujagysliniais ịvykiais [27]. Vienerių metų laikotarpiu tirti 102 ligoniai, 26\% jų buvo asimptominè PAL. Visi ligoniai stebèti 1,2 metų dèl insulto, PSIP ir kraujagyslinès mirties. Ligoniams, sergantiems insultu ar PSIP, asimptominė PAL yra nepriklausomai susijusi su pasikartojančiais kraujagysliniais ịvykiais ir insultu [28]. Tirta 1000 ligonių. PAL buvo 965 (659 vyrams). Ligonių vidutinis amžius $70 \pm 8$ metai, 77\% ligonių rūkè, 188 sirgo CD. 392 ligoniai praeityje patyrè insultą, 77 - PSIP, 298 - ūmų koronarinị sindromą, 253 - MI. 625 ligoniai PAL nesirgo, 322 sirgo lengva ir vidutinio sunkumo PAL, 18 - sunkia PAL. Bendrasis PAL paplitimas buvo 35,3\%. PAL yra dažna tarp sergančiujų cerebrovaskuline ar koronarine liga [29]. 204 üminiu išeminiu insultu ir PSIP sergantys ligoniai buvo stebėti 2,3 metų. Žemas KŽI nustatytas 63 (31\%) ligoniams ir buvo susijęs su vyresniu amžiumi, rūkymu, hipertenzija, PAL, kaklo ir intrakranijinèmis stenozèmis. Ligoniams, kuriems nustatytas žemas KŽI, buvo 2 kartus didesnè insulto, MI ar kraujagyslinès mirties rizika, palyginus su ligoniais, kurių KŽI buvo nepakitęs [30]. Mūsų tyrimo duomenimis, išeminio insulto atveju KŽI buvo ženkliai sumažèjęs - 0,46 $\pm 0,27$. Tirti 977 vyresni nei 50 metų ligoniai, patyrę nekardioembolinị PSIP ar išeminį insultą. 651(66,7\%) buvo vyrai, vidutinis amžius $-69,1$ metų. PAL diagnozuota $(K Z ̌ I=0,9) 396(40,5 \%)$ ligoniams. Asimptomè PAL nustatyta 321(35,6\%) ligoniui. Asimptomė PAL dažniausiai pasireiškia vyresnio amžiaus ligoniams, sergantiems arterine hipertenzija, esant dauginių kraujagyslinių pažeidimų ir aterotrombozinei išeminio insulto etiologijai [31].

Tirta CRB prognostinè reikšmė simptomine PAL sergan- 
tiems ligoniams. CRB kiekis buvo nustatomas 452 simptomine PAL sergantiems ligoniams 2,1 1,1,4 metų laikotarpiu. Ivykiai buvo traktuojami kaip pirminiai (mirtis, amputacija, revaskuliarizacija) ar antriniai (kojos arterijų trombozè, MI, insultas). CRB buvo ženkliai padidèjęs tarp mirusiujjų $(\mathrm{p}=0,4)$ ir ligonių, kuriems reikejo amputacijos $(\mathrm{p}=0,01)$. CRB kiekio padidejjimas yra susijęs su padidejjusia širdies-kraujagyslinių ịvykių rizika. CRB yra prognostinis kardiovaskulinių îvykių žymuo, sergant PAL [32]. Mūsų duomenimis, sergančių PAL ir patyrusių išeminị insultą ligonių CRB koncentracija kraujo serume buvo padidejjusi, tačiau, palyginus su sergančiuju LGSI grupe, statistinio patikimumo negauta. Padidèjęs fibrinogeno kiekis yra subklinikinès aterosklerozès žymuo, turintis reikšmę asimptomių asmenų, sergančių širdies ir kraujagyslių ligomis, nustatymui [5]. Išeminio insulto atveju mūsų tirtiems PAL sergantiems ligoniams fibrinogeno kiekio padidejimas buvo statistiškai patikimas, palyginus su LGSI sergančiujų grupe. Statistiškai patikimas fibrinogeno kiekio padidejjimas buvo ir praeityje išeminị insultą patyrusiems ligoniams. Nors genetiniai ir epidemiologiniai tyrimai patvirtina, kad asmenims, kuriems padidèjęs lipoproteino (a) [Lp (a)] kiekis, yra padidejusi PAL rizika, jos prognozuojama reikšmė nèra įvertinta.

Tirti 1503 ambulatoriniai ligoniai. Vertinta MI, išeminio insulto ir galūnių amputacijos rizika, atsižvelgiant ị Lp (a) koncentraciją kraujo serume. Ambulatoriniams ligoniams, kuriems pasireiškè simptominė PAL ir Lp (a) koncentracija $>30 \mathrm{mg} / \mathrm{dl}$, buvo 5 kartus didesne $\mathrm{MI}$, išeminio insulto ir galūnès amputacijos rizika. Ligoniams, kurių Lp (a) koncentracija $>50 \mathrm{mg} / \mathrm{dl}$, rizika buvo 10 kartų didesné [33]. Hiperhomocisteinemija yra senyvo amžiaus ligonių insulto rizikos veiksnys, tačiau neaišku, ar ji taip pat svarbi jaunu ligonių insulto ar PSIP atsiradimui. Tirtas homocisteino koncentracijos kraujo plazmoje poveikis recidyvuojančiu kraujagyslinių ìvykių rizikai 161 18-45 metų ligoniui, kuriam neseniai ịvyko insultas, PSIP, plaučių embolija, venų trombozè, MI ar PAL. Jauniems asmenims, sergantiems išeminiu insultu ar PSIP, homocisteino koncentracijos kraujo plazmoje padidèjimas turi reikšmès pasikartojantiems kraujagysliniams ịvykiams [34].

Šiuolaikinè simptominès PAL gydymo strategija apima kardiovaskulinių rizikos veiksnių mažinimą, t.y. rūkymo nutraukimą, hipertenzijos ir CD gydymą, cholesterolio kiekio normalizavimą. Išeminių îvykių prevencijai sergantiems PAL reikia skirti antiagregantus. Antiagregantais buvo gydomi visi mūsų tirti ligoniai. Ligonių protarpinio šlubumo gydymui skiriami medikamentai ir gydomosios mankštos pratimai. Ieškoma naujų gydymo metodų sergantiems protarpiniu šlubumu $[9,15,35]$. Aspirinas, aspirinas ir dipiridamolis, tiklopidinas, klopidogrelis yra veiksmingi gydant PAL. CAPRIE studijos duomenys parodè, kad $75 \mathrm{mg}$ klopidogrelio skyrimas sergantiems PAL 24\% sumažino kraujagyslinès mirties, MI ir insulto riziką (efektyvesnis nei $325 \mathrm{mg}$ aspirino parai) [36]. Tirtas cilostazolio poveikis vaikščiojimo distancijai ir širdies kraujagyslinių įvykių mažinimui, sergantiesiems protarpiniu šlubumu. Skiriant cilostazoli $100 \mathrm{mg} 2$ kartus per parą, vaikščiojmo distancija pailgėjo nuo 21,3 iki 40,9 metrų, palyginus su placebu [7]. Lipidų modifikacija (ypač statinais) yra PAL sergančių ligonių gydymo sudedamoji dalis. Nustatyta, kad statinai mažino naujų koronarinių įvykių atsiradimą PAL sergantiems ligoniams. Statinai gali padidinti ir sergančiuju PAL vaikščiojimo distanciją. Yra įrodymų, kad statinai gali pagerinti šių ligonių inkstų funkciją. PAL sergančius ligonius reikètų kuo anksčiau gydyti statinais [37]. Tirti 932 ligoniai, sergantys PAL. Galvos smegenų infarktas KT nustatytas 56,8\% ligonių. Tyrimo eigoje mire 413 (44,3\%) ligonių, iš jų nuo širdies ir kraujagyslių ligų mire 53,5\%. 3, 5 ir 10 metų išgyvenamumo rodikliai buvo atitinkamai $82 \%, 76,9 \%$ ir $46,2 \%$ ligonių. KT nustatytas galvos smegenų infarktas buvo nepriklausomas mirtingumo, cerebrovaskulinių ịvykių, išgyvenamumo, nesant didelių nepageidaujamų širdies ir kraujagyslių bei periferinès kraujotakos sutrikimų, žymuo [38]. Pirmą kartą COMPASS studijoje buvo tiriamas mažos dozès antikoaguliantų skyrimas stabilios KŠL ar PAL atveju. Pridejjus 2,5 mg rivaroksabano 2 kartus dienoje ilgalaikiam gydymui aspirinu, buvo užkirstas kelias širdies ir kraujagyslių ligoms, MI ir insultui, 18\% sumažintas mirtingumas vidutiniškai 23 mènesiams. Svarbu tai, kad nepadidèjo mirtinas ir intrakranijinis kraujavimas [39]. Tirta 1029 PAOL sergančiu ligonių, aspirinas (su dipiridamoliu ar be jo) lyginamas su placebu. Rekomenduojama visą laiką vartoti mažas (75-150 mg parai) aspirino dozes, klopidogreli paliekant ligoniams, netoleruojantiems aspirino [40]. Turimi duomenys rodo, kad aspirinas sumažina sergamumą PAL ir mirtingumą nuo jos, o klopidogrelis sumažina aterotrombozinių reiškinių, tokių kaip MI ir insultas, riziką šiems ligoniams [11]. Apibendrinti trijų studijų (ESLA1, APRES, PRISMA) duomenys, siekiant apibūdinti širdies ir kraujagyslių ligų rizikos veiksnių paplitimą ir aterotromboze sergančių ligonių vaistų vartojimo būdus. Tirti 14544 ligoniai (vyrų 75\%, 75 metų ir vyresni $31,0 \%$ ). Bent vienas iš keturių pagrindinių rizikos veiksnių (rūkymas, hipertenzija, hipercholesterolemija, diabetas) sudare $94,3 \%$ atvejų. 78,8\% ligoniu skirti antiagregantai, $48,5 \%$ - statinai, $36,7 \%$ - beta adrenoblokatoriai, 33,4\% angiotenziną konvertuojančio fermento inhibitoriai (AKFI). Statinai buvo dažniausiai skiriami ligoniams, patyrusiems izoliuotą MI. Izoliuotas MI, palyginus su išeminiu insultu ir PAL, buvo reikšmingai ir nepriklausomai susijęs su didesne tikimybe vartoti antiagregantus, beta blokatorius ir AKFI [41]. İvertintas aspirino ir didelès dozès antioksidantų derinio profilaktinis veiksmingumas ligoniams, sergantiems PAL, mažinant MI, insulto, kraujagyslinès mirties ir galūnès kriti- 
nès išemijos riziką. Nebuvo įrodymų, kad antioksidantai vitaminai yra naudingi kraujagyslinių įvykių prevencijai. Mažos aspirino dozès sumažino kraujagyslinių ịvykių dažnį 26\%. Mažų dozių aspirinas turi būti skiriamas PAL sergantiems ligoniams kraujagyslinių ịvykių prevencijai [42]. Metimas rūkyti, lipidų profilio gerinimas, kraujospūdžio mažinimas ir antiagregantų vartojimas sumažina kraujagyslinių ịvykių riziką PAL sergantiems ligoniams [43]. Atlikta aterotrombozinèmis ligomis sergančių ligonių sisteminė apžvalga ir metaanalizè, nustatant cilostazolio poveikị smegenų, širdies ir visų kraujagyslių ligoms. Studijos duomenys parodè statistiškai reikšmingą cerebrovaskulinių sutrikimų rizikos sumažejjimą aterotromboze sergantiems ligoniams, nesant padidejjusio kraujavimo rizikos [44]. Antiagregantai yra skiriami visiems PAL sergantiems ligoniams. Statinai skiriami norint pasiekti tikslinị mažo tankio lipoproteinų cholesterolio kieki $-\leq 2,5 \mathrm{mmol} / 1$. Skirtini visų grupių antihipertenziniai vaistai, tačiau sergantiems PAL ypač tinka AKFI ramiprilis ar perindoprilis, nes jie sumažina širdies ir kraujagyslių ligų dažnị. Farmakologinė antrinė širdies ir kraujagyslių ligų bei mirtingumo nuo jų prevencija sergantiems PAL turi būti tokia, kaip ligoniams, sergantiems koronarine ar cerebrovaskuline liga [45]. PAL paplitimas tarp sergančiųų išeminiu insultu yra didelis. Pirminejje ir antrinejje insulto prevencijoje PAL rodo didelę galimų kraujagyslinių ịvykių riziką [46].

PAL ir išeminis insultas yra aterosklerozés klinikinès apraiškos. Šių ligų glaudus tarpusavio ryšys. PAL sergantiems ligoniams neretai pasireiškia PSIP, ịvyksta insultas. Mažejjant KŽI, insulto rizika didejja. PAL gydymui ligoniams skiriami antiagregantai, jų skyrimas yra ir išeminio insulto prevencija. Kadangi nustatytas ryšys tarp PAL ir insulto atsiradimo esant ribinei PAL, išeminio insulto prevencijai asimptominės PAL atveju reikia skirti antiagregantus.

\section{Išvados}

1. Periferinių arterijų liga yra išeminio insulto rizikos veiksnys. Ji dažnai susijusi su išeminiu insultu.

2. Išeminio insulto atveju ir patyrus išeminị insultą praeityje, sergančiujų periferinių arterijų liga fibrinogeno koncentracijos kraujo serume padidèjimas, palyginus su lètine galvos smegenų išemija sergančiujų grupe, yra statistiškai patikimas.

3. Žemas kulkšnies-žasto indeksas rodo subklinikinę periferinių arterijų ligą ir insulto riziką. Esant asimptominei periferinių arterijų ligai, išeminio insulto prevencijai turi būti skiriami antiagregantai.

4. Išeminio insulto atveju sergančiųų periferinių arterijų liga kulkšnies-žasto indeksas yra ženkliai sumažèjęs ir atskleidžia didelę kartotino insulto ir kraujagyslinių ịvykių riziką. Kulkšnies-žasto indekso nustatymas patyrusiems iše- minį insultą gali padèti atrinkti didelès rizikos ligonius, kuriems turi būti taikoma antrinè insulto prevencija.

\section{Literatūra}

1. Lahoz C, Mastaza JM. Atherosclerosis as a systemic disease. Rev Esp Cardiol 2007;60(2):184-95. https://doi.org/10.1157/13099465

2. Rahman MS, Woollard K. Atherosclerosis. Adv Exp Med Biol 2017;1003:121-144. https://doi.org/10.1007/978-3-319-57613-8_7

3. Roquer J, Segura T, Serena J, Castillo J. Endothelial dysfunction, vascular disease and stroke: the ARTICO study. Cerebrovasc Dis 2009;27(1):25-37.

https://doi.org/10.1159/000200439

4. Gavornik P, Dukát A, Gaspar L, Oravec S, Caprnda M, Vacula I et al. Prevention and treatment of extremity vascular ischemic disease. Vnitr Lek 2010;56(6):613-9.

5. Páramo JA, Rodriguez JA, Orbe J. Fibrinogen. An old hemostatic protein with a new function: non-invasive marker of subclinical atherosclerosis. Med Clin (Barc) 2005;124(20):790-4. https://doi.org/10.1157/13075852

6. Espinola-Klein C. Peripheral artery disease: basic knowledge. Med Monatsschr Pharm 2017;40(3):95-7.

7. Robless P, Mikhailidis DP, Stansby GP. Cilostazol for peripheral arterial disease. Cochrane Database Syst Rev 2008;23(1):CD003748.

https://doi.org/10.1002/14651858.CD003748.pub3

8. Waldstein SR, Tankard CF, Maier KJ, Pelletier JR, Snow J, Gardner AW et al. Peripheral arterial disease and cognitive function. Psychosom Med 2003;65(5):757-63. https://doi.org/10.1097/01.PSY.0000088581.09495.5E

9. Milani RV, Lavie CJ. The role of exercise training in peripheral arterial disease. Vasc Med 2007;12(4):351-8. https://doi.org/10.1177/1358863X07083177

10. Olson KW, Treat-Jacobson D. Symptoms of peripheral arterial disease: a critical review. J Vasc Nurs 2004;22(3):72-7. https://doi.org/10.1016/j.jvn.2004.07.003

11. Branderry JC. Peripheral arterial disease: pathophysiology, risk factors and role of antitrombotic therapy. J Am Pharm Assoc 2004;44(1):37-44. https://doi.org/10.1331/154434504322904596

12. Chochola M, Lirhart A. Epidemiology of ischemic diseases of the lower extremities. Cas Lek Cesk 2006;145(5):368-70.

13. Dawson DL, Hiatt WR, Creager M, Hirsch AT. Peripheral arterial disease: medical care and prevention of complications. Prev Cardiol 2002;5(3):119-30. https://doi.org/10.1111/j.1520-037X.2002.00558.x

14. Pasqualini L, Marchesi S, Vaudo G, Siepi D, Angeli F, Paris $\mathrm{L}$ et al. Association between endothelial dysfunction and major cardiovascular events in peripheral arterial disease. Vasa 2003;32(3):139-43.

https://oi.org/10.1024/0301-1526.32.3.139 
15. Regensteiner JG, Hiatt WR. Treatment of peripheral arterial disease. Clin Cornerstone 2002;4(5):26-40. https://doi.org/10.1016/S1098-3597(02)90014-1

16. Sawayama Y, Hamada M, Otaguro S, Maeda S, Ohnishi H, Taira Y et al. Impact of peripheral arterial disease and acute ischemic stroke. Fukuoka Igaku Zasshi 2006;97(10):293-301.

17. Arboix A, Tarruella M, Garcia-Eroles L, Oliveres M, Miquel $\mathrm{C}$, Balcells $\mathrm{M}$ et al. Ischemic stroke in patients with intermittent claudication: a clinical study of 142 cases. Vasc Med 2004;9(1):13-7. https://doi.org/10.1191/1358863x04vm523oa

18. Meves SH, Diehm C, Berger K, Pittrow D, Trampisch HJ, Burghaus I et al. Peripheral arterial disease as an independent predictor for excess stroke morbidity and mortality in primarycare patients: 5-year results of the getABI study. Cerebrovasc Dis 2010;29(6):546-54. https://doi.org/10.1159/000306640

19. Ovbiagele B. Association of ankle-brachial index level with stroke. J Neurol Sci 2009;15;276(1-2):14-7.

https://doi.org/10.1016/j.jns.2008.08.016

20. Pang XH, Han J, Ye WL, Sun X, Ding Y, Huang WJ et al. Lower extremity peripheral arterial disease is an independent predictor of coronary heart disease and stroke risks in patients with type 2 diabetes mellitus in China. Int J Endocrinol 2017;2017:9620513.

https://doi.org/10.1155/2017/9620513

21. Rahman AS, Akhtar SW, Jamal Q, Sultana N, Siddigui MA, Hassan Z. Ischemic stroke and peripheral arterial disease. J Pak Med Assoc 2017;67(8):1138-1144.

22. Topakian R, Nanz S, Rohrbacher B, Koppensteiner R, Aicher FT; OECROSS Study Group. High prevalence of peripheral arterial disease in patients with acute ischemic stroke. Cerebrovasc Dis 2010;29(3):248-54. https://doi.org/10.1159/000267850

23. Purroy F, Oró M, Quilez A, Sanahuja J, Brieva L, Grandés P. Detection of silent peripheral arterial disease in stroke patients with a low ankle-arm index. Neurologia 2008;23(1):10-4.

24. Hoshino H, Itoh Y, Yamada S, Suzuki N. Prevalence and clinical features of asymptomatic peripheral arterial disease in Japanese stroke patients. J Stroke Cerebrovasc Dis 2013;22(3):255-9. https://doi.org/10.1016/j.jstrokecerebrovasdis.2011.08.011

25. TouzéE, Varenne O, Priollet P, Alpérovitch A, Mas JL. Prevalence of asymptomatic atherothrombotic lesions and risk of vascular events in patients with a stroke. Arch Mal Coeur Vaiss 2005;98(4):15-30.

26. Ness J, Aronow WS. Prevalence of coexistence of coronary artery disease, ischemic stroke and peripheral arterial disease in older persons, mean age 80 years, in an academic hospitalbased geriatrics practice. J Am Geriatr Soc 1999;47(10):1255-6. https://doi.org/10.1111/j.1532-5415.1999.tb05208.x

27. Ratanakorn D, Keandoungchun J, Tegeler CH. Prevalence and association between risk factors, stroke subtypes and abnormal ankle-brachial index in acute ischemic stroke. J Stroke Cere- brovasc Dis 2012;21(6):498-503.

https://doi.org/10.1016/j.jstrokecerebrovasdis.2010.11.011

28. Sen S, Lynch DR Jr, Kaltsas E, Simmons J, Tan WA, Kim J et al. Association of asymptomatic peripheral arterial disease with vascular events in patients with stroke or transient ischemic attack. Stroke 2009;40(11):3472-7.

https://doi.org/10.1161/STROKEAHA.109.559278

29. Mehlsen J, Wiinberg N, Joergensen BS, Schultz-Larsen P. High prevalence of peripheral arterial disease in patients with previous cerebrovascular or coronary event. Blood Press 2010;19(5):308-12.

https://doi.org/10.3109/08037051.2010.491178

30. Busch MA, Lutz K, Röhl JE, Neuner B, Masuhr F. Low anklebrachial index predicts cardiovascular risk after acute ischemic stroke or transient ischemic attack. Stroke 2009;40(12):3700-5. https://doi.org/10.1161/STROKEAHA.109.559740

31. Alvarez-Sabin J, Gil-Núňez A, Quintana M, Barbera G. Prevalence of asymptomatic peripheral arterial disease in patients with non-cardioembolic ischemic stroke. Neurologia 2009;24(6):366-72.

32. Hogh AL, Joensen J, Lindholt JS, Jacobsen MR, Ostergaard L. $\mathrm{C}$-reactive protein predicts future arterial and cardiovascular events in patients with symptomatic peripheral arterial disease. Vasc Endovascular Surg 2008;42(4):341-7. https://doi.org/10.1177/1538574408316138

33. Sanchez Muňoz-Torrero JF, Rico-Martin S, Álvarez LR, Aguilar E, Alcald JN, Monreal M. Lipoprotein (a) levels and autcomes in stable outpatients with symptomatic arterial disease. Atherosclerosis 2018;276:10-14. https://doi.org/10.1016/j.atherosclerosis.2018.07.001

34. Bos MJ, van Goor ML, Kondstaal PJ, Dippel DW. Plasma homocysteine is a risk factor for recurrent vascular events in joung patients with an ischemic stroke or TIA. J Neurol 2005;252(3):332-7.

https://doi.org/10.1007/s00415-005-0647-9

35. Desormais I, Aboyans V, Pesteil F, Lacroix P. Peripheral arterial disease: treatment. Presse Med 2018;47(1):56-61.

https://doi.org/10.1016/j.lpm.2017.09.019

36. Aronow WS. Antiplateled therapy in peripheral arterial disease. Curr Drug Targets Cardiovasc Haematol Disord 2004; 4(3):265-7. https://doi.org/10.2174/1568006043336104

37. Alnaeb ME, Alobaid N, Seifalian AM, Michailidis DP, Hamilton G. Statins and peripheral arterial disease: potential mechanisms and clinical benefits. Ann Vasc Surg 2006;20(5):696-705. https://doi.org/10.1007/S10016-006-9104-1

38. Kumakura H, Kanai H, Matsuo Y, Iwasaki T, Ichikawa S. Asymptomatic cerebral infarction is a predictor of long-term survival and vascular or limb events in peripheral arterial disease. Eur Heart J Qual Care Outcomes 2019;5(1):43-50. https://doi.org/10.1093/ehjqcco/qcy024 
39. Al Said S, Bode C, Duerschmied D. Anticoagulation in atherosclerotic disease. Hemostaseologie 2018;38(4):240-246. https://doi.org/10.1055/s-0038-1673412

40. Lechat P, Priollet P. Prevention of major ischemic events in lower limb arterial disease: does aspirin play a role? J Mal Vasc 2006;31(3):129-34. https://doi.org/10.1016/S0398-0499(06)76531-3

41. Bongard V, Cambou JP, Lezorovez A, Ferrères J, Vahanan A, Jullen $\mathrm{G}$ et al. Comparison of cardiovascular risk factors and drug use in 14544 French patients with a history of myocardial infarction, ischemic stroke and/or peripheral arterial disease. Eur J Cardiovasc Prev Rehabil 2004;11(5):394-402. https://doi.org/10.1097/00149831-200410000-00006

42. Catalano M, Born G, Peto R. Prevention of serious vascular events by aspirin amongst patients with peripheral arterial disease: randomized, double-blind trial. J Intern Med 2007; 261(3):276-84.

https://doi.org/10.1111/j.1365-2796.2006.01763.x

43. Youssef F, Gupta P, Mikhailidis DP, Hamilton G. Risk modification in patients with peripheral arterial disease: a retrospective survey. Angiology 2005;56(3):279-87. https://doi.org/10.1177/000331970505600307

44. Uchiyama S, Demaerschalk BM, Goto S, Shinobara Y, Gotoh F, Stone WM et al. Stroke prevention by cilostazol in patients with atherothrombosis: meta-analysis of placebo-controlled randomized trials. J Stroke Cerebrovasc Dis 2009;18(6):482-90. https://doi.org/10.1016/j.jstrokecerebrovasdis.2009.07.010

45. Blinc A, Poredos P. Pharmacological prevention of atherothrombotic events in patients with peripheral arterial disease. Eur J Clin Invest 2007;37(3):157-64. https://doi.org/10.1111/j.1365-2362.2007.01767.x

46. Banerjee A, Fowkes FG, Rothwell PM. Associations between peripheral arterial disease and ischemic stroke: implications for primary and secondary prevention. Stroke 2010,41(9):2102-7. https://doi.org/10.1161/STROKEAHA.110.582627

\section{TRANSIENT ISCHEMIC ATTACK, ISCHEMIC STROKE AND PERIPHERAL ARTERIAL DISEASE \\ L. Kimševaitė, N. Markevičius}

Keywords: transient ischemic attack, ischemic stroke, peripheral arterial disease.

Summary

Objective. To analyse cerebrovascular disorders in patients suffering from the peripheral arterial disease, focusing on the correlation between the ischemic stroke and the peripheral arterial disease.

Materials and methods. From February 2017 to June 2019 we studied 28 patients (10 females, 18 males) suffering from the peripheral arterial disease and cerebrovascular disorders, who were treated in the Departments of Angiosurgery, Invasive Radiology and Endoprosthetic Surgery as well as in the Angiosurgery Anaes- thesiology and Reanimatology Department. The patients' age was from 49 to 87 years (the average age was $73,2 \pm 1,9$ years). The average duration of in-hospital treatment was 7,7 days. The control group included 11 patients suffering from chronic cerebral ischemia. General blood count and biochemical tests (serum fibrinogen and C-reactive protein tests, lipidogram) were carried out for all the patient as well as electrocardiogram recording and conventional angiography; the ankle-brachial index was assessed in the part of the patients, and cerebral computed tomography and magnetic resonance imaging were performed as indicated. The means of the statistical data were assessed using the Student's t-test. The differences were considered as statistically significant, if $\mathrm{p}$ value was $<0,05$.

Results. Cerebrovascular disorders in the patients with the peripheral arterial disease were analysed. A transient ischemic attack was diagnosed in $9(32,1 \%)$ patients, ischemic stroke was diagnosed in $5(17,9 \%)$, consequenses of the ischemic stroke were found in 14 $(50,0 \%)$ patients. It was discovered that after a transient ischemic attack serum fibrinogen and C-reactive protein levels were increased to $3,62 \pm 0,06 \mathrm{mg} / 1$ and $1,82 \pm 1,31 \mathrm{~g} / \mathrm{l}$ respectively. In case of the ischemic stroke, the serum fibrinogen level was $5,25 \pm 0,8 \mathrm{~g} / 1$, and in patients with chronic cerebral ischemia $-2,18 \pm 0,35 \mathrm{~g} / \mathrm{l}(\mathrm{p}<0,02)$. Serum C-reactive protein levels were $70,67 \pm 41,11 \mathrm{mg} / \mathrm{l}$ in the patients suffering from the ischemic stroke and 2,02 $\pm 0,43 \mathrm{mg} / \mathrm{l}$ in the patients with chronic cerebral ischemia $(p>0,05)$. The ankle-brachial index was $0,46 \pm 0,27$ during the period of the acute ischemic stroke. Serum fibrinogen levels were $4,92 \pm 0,65 \mathrm{~g} / 1$ in the patients with the consequenses of the ischemic stroke and $2,18 \pm 0,35 \mathrm{mg} / 1$ in those suffering from chronic cerebral ischemia $(\mathrm{p}<0,01)$. C-reactive protein levels were $57,99 \pm 36,05 \mathrm{mg} / \mathrm{l}$ in the patients with the consequenses of the ischemic stroke and 2,02 $\pm 0,43 \mathrm{mg} / \mathrm{l}(\mathrm{p}>0,05)$ in the patients diagnosed with chronic cerebral ischemia. The clinical cases were presented. The newest scientific publications on the peripheral arterial disease and the ischemic stroke, including the combination of these diseases, were reviewed.

Conclusions. 1. The peripheral arterial disease is a risk factor of the ischemic stroke. The peripheral arterial disease is commonly associated with the ischemic stroke. 2 . In case of the ischemic stroke and in patients with the history of the ischemic stroke, the increase in serum fibrinogen levels is statistically significant as compared with the group of patients suffering from chronic cerebral ischemia. 3. The low ankle-brachial index indicates the subclinical course of the peripheral arterial disease and the risk of a stroke. Antiagregants should be administered for ischemic stroke prevention in case of the asymptomatic peripheral arterial disease. 4 . The ankle-brachial index was significantly lowered in case of the ischemic stroke and indicated a high risk of the repeated stroke and vascular events. Evaluation of the ankle-brachial index in patients after the ischemic stroke can help to identify high-risk patients to whom the secondary stroke prevention is necessary.

Correspondence to: liudmila.kimsevaite@gmail.com

Gauta 2019-09-11 